\title{
THE VALUE OF BLOCKHOLDERS SHAPED BY MODERATORS
}

\author{
Maurizio La Rocca ${ }^{1}$, Fabiola Montalto ${ }^{2}$ \\ 1,2 Department of Business and Legal Sciences, University of Calabria, Cubo 3C, \\ Campus di Arcavacata, Via P. Bucci, 87036 Rende (CS), Italy \\ ${ }^{2}$ Department of Accounting and Finance, University of AntwerpStadscampus, \\ Prinsstraat 13, 2000 Antwerpen, Belgium \\ E-mails: ${ }^{1}$ m.larocca@unical.it (corresponding author); ${ }^{2}$ fabiola.montalto@unical.it \\ Received 20 September 2012; accepted 08 April 2013
}

\begin{abstract}
This paper investigates the role of moderators in affecting the relationship between ownership and value. The results generally reveal a positive influence of blockholders on performance, that is significantly affected by moderating factors. The link becomes negative in listed firms, as well as in family ones, and vanishes in financial constrained ones. Moreover, in case of managerial opportunism, the role of blockholders increases the positive effect of ownership on performance. Conversely, new governance reforms, improving the investors' protection, have resized the centrality of the majority shareholder. Overall, results can be used to make recommendations on how to improve corporate and country-specific governance mechanisms.
\end{abstract}

Keywords: corporate governance, blockholders, moderating variables, performance.

Reference to this paper should be made as follows: La Rocca, M.; Montalto, F. 2013. The value of blockholders shaped by moderators, Journal of Business Economics and Management 14(Supplement 1): S313-S327.

JEL Classification: G30, G32.

\section{Introduction}

Empirical studies on the effect of ownership concentration on performance began in the 1980s, revealing the absence of a relationship due to endogeneity (Demsetz 1983; Demsetz, Lehn 1985). Subsequently, studies focused on advantages and disadvantages of ownership. With reference to benefits, according to the monitoring hypothesis, the relationship between ownership concentration and performance would be positive in case of conflicts between managers and shareholders, thanks to the active role of large shareholders in limiting managerial discretion and expropriation of value (Shleifer, Vishny 1986, 1997). With regard to the detriments, according to the expropriation hypothesis, the relationship may be negative because of opportunistic behavior adopted by blockholders (Leech, Leahy 1991; Shleifer, Vishny 1997). A further perspective study combines the potential advantages and disadvantages, arguing that the predominant effect depends on the level of ownership (Miguel et al. 2004; Gedajlovic, Shapiro 1998). 
This paper uses Italy as empirical setting, since it is a context in which blockholders strictly affect the companies' modus operandi. Italy is a civil law country where ownership concentration is high and in which being the majority shareholder is a tool for the protection of own interests. The high level of ownership concentration involves a strong influence by the large shareholders in the firm governance. On the one hand, a greater ownership concentration, increasing the sense of belonging to the firm and responsibilities of blockholders, can lead to a more efficient corporate governance, that could result in higher performance: for this reason, it is appropriate to talk about "incentive effect". On the other hand, the Italian largest shareholder may amplify problems of opportunism. The Italian system is generally regarded as a poorly functioning one because of its weak legal protection of small shareholders (La Porta et al. 1999, 2000) and its underdeveloped capital markets. For this reason, there are relevant risks of private benefit extraction by large shareholders (agency problems of type II).

The empirical literature in the Italian context, similarly to the international one, highlights controversial findings: Fratini, Tettamanzi (2007), for example, do not obtain statistically significant results; some scholars found positive links (Volpin 2002), other ones negative (Barucci, Cecacci 2005). The contradictions that emerge in the Italian and international literature may be caused by the role of moderating factors: the relationship between ownership and performance may be classified depending on the effect of moderation of firm-specific or institutional variables, which, interacting with ownership, change its consequences on the processes of value creation. This paper seeks to understand the influence of moderating factors that may determine the prevalence of the incentive rather than the expropriation effect, altering the direction and intensity of the link. As a contribution to the literature, our paper not only seeks to give an explanation to conflicting results found in previous studies, but it considers several moderating variables, both firm-specific and related to the institutional context, embracing the theoretical perspectives of Agency Theory and Law and Finance View. Overall, the results can be used to make recommendations on how to improve corporate and country-specific governance mechanisms.

The next section describes the model and assumptions, while the following one presents the empirical results. The concluding remarks focuses on managerial implications and future research directions.

\section{Model and assumptions}

\subsection{Research hypothesis}

The link between ownership and performance is not isolated, suggesting a number of potential moderating factors. In this regard, the research hypotheses based on the Italian context are explained as follows:

H1: The relationship between ownership and performance is moderated by debt.

Capital structure is able to affect the efficiency of firm governance, moderate economic transactions within firms and change the allocation of resources (Coase 1992; Myers 2000; Williamson 1988). Debt and equity should be considered governance instruments: 
debt subordinates firms to more stringent management rules, while equity allows for greater flexibility and discretion. In this respect, Jensen, Meckling (1976) and Pindado, De La Torre (2011) describe the link between ownership and capital structure. To verify how the capital structure influences firm governance, we test whether the use of debt modifies the incentives of large shareholders to support the business. Firm leverage may limit the possibilities for development of firm performance, so we expect a negative moderating effect. An interaction variable between leverage and ownership is used for this purpose. In addition, we use as moderating variable a dummy indicating the case of very indebted firms, equal to 1 when debt ratio is more than $75 \%$. Moreover, the effect is also measured through an interaction between ownership concentration and a dummy variable equal to 1 for firms with high debt and poor ability to meet commitments to creditors, in order to take into account firms where capital structure generates severe financial constraint problems.

H2: Probability of managerial opportunism shapes the relationship between ownership and performance.

Conflicts of interest are particularly relevant in the presence of firms with high free cash flow. According to agency theory, management tends to hoard cash whenever possible to build up the resources under its control (Jensen 1986). With abundant free cash flow and high discretionary power, the manager is more likely to undertake low-benefit or even value-destroying decisions, in order to obtain higher compensations, power and prestige. Moreover, agency costs of type I, related to the presence of free cash flow, are exacerbated in case of low levels of debt (Jensen 1986; Shleifer, Vishny 1997). In these situations, the role of blockholders may be conditioned by a stronger monitoring effect towards management, so we expect a positive moderating effect. To test this, we use an interaction between ownership concentration and a dummy variable equal to 1 for firms with low debt and high free cash flow.

H3: The relationship between ownership and performance is moderated by family control.

Family control may have relevant implications for business activities (Faccio, Lang 2002), particularly in bank-based countries, with low investors' protection and an inefficient market for corporate control. Although the sense of responsibility increases among the family members involved in the business, opportunistic problems between the family and minority shareholders may be particularly relevant, especially in contexts where financial markets are underdeveloped (Faccio et al. 2001). In summary, the positive effect of family control in reducing agency problems of type I may be more than offset by significant conflicts between family shareholders and minority investors (Maury 2005). To test this, we use an interaction variable between ownership concentration and a dummy equal to 1 in the case of a family-controlled firm.

H4: The relationship between ownership and performance is moderated by listing status.

A possible adverse relationship between large shareholders and small investors comes with listing. In the presence of an inefficient institutional framework, with a poorly 
developed financial market and a lack of legislative actions, as in the Italian case, the low level of investor protection creates dangerous situations of opportunism (La Porta et al. 2008): listing status may generate potential agency problems between who has control and investors (Loderer, Waelchli 2010). In Italy, these problems especially concern conflicts between majority shareholders and minority investors. If the institutional framework does not sufficiently protect small shareholders of a listed firm, there will be opportunities for who has control to expropriate value. Therefore, the performance consequence of ownership can be affected by more expropriation problems in the case of listed firms, so the effect of moderation should be negative. To verify this, we consider the interaction between ownership concentration and a dummy equal to 1 if the firm is listed.

H5: The relationship between ownership and performance is moderated by the introduction of legal reforms.

Historically, Italian law has provided weak protection and poor enforcement for investors. Compared to the past, however, many reform acts have been introduced since 1998. In particular, the first important reform was the TUF (Law 58/1998, also known as the "Draghi Law"), that has led to greater disclosure, an increase in minority representation in assemblies and in the activism on the part of institutional investors (Mengoli et al. 2009). Since 1998, many other Reforms have followed: a corporate governance code, introduced in 1999, affecting business activity through the development of best practice guidelines with a coercive effect for corporate governance; the Corporate Law Reform in 2004 (the so called "Vietti Law"); the 62/2005 law and the 262/2005 law, concerning market abuse and the protection of savings; a number of regulations to enhance financial disclosure and transparency (Law 195/2007) and to regulate tender offers on the stock market (Law 229/2007). In order to verify whether the introduction of reforms in the legal system, increasing protection for investors and, then, reducing the centrality of the majority shareholder to value creation, has had a negative moderating effect on the relationship between ownership and performance, we test the interaction between ownership and a dummy variable equal to 1 for the years equal to or later than 1998, when the first reform (the TUF) came into force.

H6: The relationship between ownership and performance is moderated by the development of the financial system.

The Italian financial system is bank-based. A radical regulatory Bank Reform, which started in 1990, has led to a positive increase in the system's efficiency, more effective financial support to firms and a further control over opportunistic behaviors. Therefore, the effect of ownership concentration on performance should be reduced by these changes, as well as is the case of improvement of the legal system. We consider the interaction between ownership and a dummy equal to 1 for the years equal to or later than 1990, when the Bank Reform Act was introduced. In addition, we also consider the interaction between ownership concentration and a proxy of bank development.

H7: The relationship between ownership and performance is moderated by financial crisis. 
In times of crisis, a higher level of ownership concentration is associated with superior performance (Desender et al. 2008); in fact, the positive contribution offered by ownership may be stronger, since a majority shareholder could support the firm in facing financial constraint problems. Thus, ownership can have an active role in supporting firm financial needs, so we expect a positive moderating effect. Therefore, to test the role of ownership on firm performance during crisis periods, we use the interaction between ownership concentration and a dummy variable equal to 1 for the years 2008 and 2009 .

\subsection{Empirical model}

This study aims to analyze the relationship between ownership concentration and performance through a basic model, in which the role of moderator variables is introduced. Similarly to Cornett et al. (2007) and Denis, Kruse (2000), as proxy of performance, we use an industry-adjusted operating cash flow return on assets based on the ratio between EBITDA and total asset. Industry-adjusted comparisons allow us to examine firm-specific performance irrespective of any industry-factors that may affect ROA. In particular, the measure of operating performance is corrected by subtracting, from the value of the indicator for every firm and year, the mean value obtained from firms with similar size belonging to the same industry, in accordance with Pavitt's taxonomy(1984). Cash flow ROA, without reflecting growth opportunities, it is not inflated by expectations on the stock market and is less affected by endogeneity problems.

The variable referring to ownership concentration is measured by the proportion of shares held directly by the largest shareholder (Lehmann, Weigand 2000; Perrini et al. 2008). The share of the largest shareholder indicates his ability to outvote other shareholders or initiate major changes by himself. Most research has followed Demsetz and Lehn (1985) in measuring concentration with respect to a group of owners. Yet the group measure may be ineffective if a very large owner is present, as in many Italian firms. In this case, the marginal contributions of other smaller blockholders are minor, then the inclusion of their shareholdings in the concentration variable rises measurement error, reducing the magnitude of the estimated performance effect and increasing the standard error (Earle et al. 2005). In any case, jointly with our measure of ownership we also use a variable calculated as the sum of the percentage of shares directly held by the first 3 shareholders.

Taking into account the previous literature (Miguel et al. 2004; McConnell, Servaes 1990; Perrini et al. 2008) and after testing several econometric specifications, we have used leverage, tangibility and growth opportunity as control variables. The variables used are described in detail in Appendix 1. In addition, the model includes dummies for each year of observation. The identification of the "best" model is determined passing from more general specifications to gradually more parsimonious ones. In fact, in the first instance the model also included firm age and firm size; however, these variables were not statistically significant, and their inclusion does not changed the estimates, neither increase the explanatory power of the model, so we remove them in order to have a more parsimonious model. 


\section{Empirical analysis}

\subsection{Sample analysis and descriptive statistics}

The unbalanced panel data sample of the analysis consists of both listed and unlisted Italian firms, for the period 1980-2009. Mediobanca Ricerche \& Studi provides the firm-level data. Thereafter, we collect the macro-level data using the World Bank and Borsa Italiana - BiStat databases. The initial sample is composed of 2,734 observations. The selection process starts by eliminating outliers to avoid distortions in the estimates. Second, firms belonging to the financial and insurance sectors are not selected, as well as entities involved in "abnormal" situation (i.e. Parmalat, Cirio and Alitalia). Third, observations for which all necessary data are not available are eliminated. Therefore, the final sample consists of 229 firms and 2,586 observations.

Table 1 provides descriptive statistics.

Panel A reports results for the full sample. As expected given the literature on the Italian ownership structure, the level of ownership concentration is very high: the majority shareholder owns on average more than $60 \%$ of equity. The range of values that can take the industry-adjusted performance measure is from -0.49 to 0.93 , with mean value close to 0 , as a standardized measure. Panel B reports descriptive results for the listed

Table 1. Descriptive statistics

\begin{tabular}{|c|c|c|c|c|}
\hline Variables & Obs & Mean & Stand. Dev. & Median \\
\hline \multicolumn{5}{|c|}{ Panel A: Full Sample } \\
\hline Adj_Cfroa & 2,586 & 0.00 & 0.14 & -0.02 \\
\hline Ownership Concentration & 2,586 & 0.66 & 0.26 & 0.64 \\
\hline Leverage & 2,586 & 0.42 & 0.23 & 0.42 \\
\hline Tangibility & 2,586 & 0.33 & 0.16 & 0.33 \\
\hline Growth opportunities & 2,586 & 0.09 & 0.23 & 0.06 \\
\hline \multicolumn{5}{|c|}{ Panel B: Listed Firms } \\
\hline Adj_Cfroa & 893 & -0.04 & 0.11 & -0.05 \\
\hline Ownership Concentration & 893 & 0.49 & 0.20 & 0.51 \\
\hline Leverage & 893 & 0.40 & 0.20 & 0.41 \\
\hline Tangibility & 893 & 0.40 & 0.17 & 0.38 \\
\hline Growth opportunities & 893 & 0.09 & 0.23 & 0.07 \\
\hline \multicolumn{5}{|c|}{ Panel C: Unlisted Firms } \\
\hline Adj_Cfroa & 1693 & 0.02 & 0.15 & 0.00 \\
\hline Ownership Concentration & 1693 & 0.74 & 0.25 & 0.80 \\
\hline Leverage & 1693 & 0.42 & 0.24 & 0.43 \\
\hline Tangibility & 1693 & 0.33 & 0.16 & 0.31 \\
\hline Growth opportunities & 1693 & 0.10 & 0.22 & 0.06 \\
\hline
\end{tabular}


firms' subsample. As expected, the average level of ownership concentration is lower (49\%); it is known that ownership of listed companies is more fragmented, even if, in the Italian case, the level of concentration is still high on average. In addition, in this subsample, average performance appears to be lower. Panel $\mathrm{C}$ shows the descriptive statistics for unlisted firms. The average ownership concentration is very high $(74 \%)$, in line with expectations, while the performance, on average, seems to be better than listed companies.

In general, problems of correlations due to multicollinearity are negligible, as obtained from correlation matrix and VIF test, not shown for reasons of brevity.

\subsection{The relationship between ownership concentration and performance}

The paragraph describes the analysis on the relationship between ownership concentration and performance. The selected estimation method, able to avoid problems of endogeneity and unobserved heterogeneity, is the system generalized method of moments (GMM) (Blundell, Bond 1998). Table 2 describes the results regarding the basic model.

With reference to column 1 of Table 2, the model shows the desired statistical properties in terms of efficiency and consistency of the estimators. The Hansen test, in the two-step GMM regression, represents a test of over-identifying restrictions, asymptotically distributed as a chi-square under the null hypothesis of no correlation between the instruments and the error term. In this case, the value of the test leads to non-rejection

Table 2. The relationship between ownership and firm performance

\begin{tabular}{lccc}
\hline \multicolumn{1}{c}{ Variables } & $(1)$ & $(2)$ & $(3)$ \\
& Adj_Cfroa & Adj_Cfroa & Adj_Cfroa \\
\hline Ownership Concentration & $0.05^{* *}$ & -0.17 & \\
& $(0.02)$ & $(0.12)$ & \\
\hline Ownership Concentration 2 & \multicolumn{3}{c}{0.16} \\
& & $(0.10)$ & $0.09^{* *}$ \\
Ownership Concentration 3 & & & $(0.04)$ \\
\hline Leverage & $-0.25^{* * *}$ & $-0.23^{* * *}$ & $-0.23^{* * *}$ \\
& $(0.04)$ & $(0.04)$ & $(0.04)$ \\
\hline Tangibility & $-0.09^{* *}$ & $-0.08^{* *}$ & $-0.08^{* *}$ \\
& $(0.04)$ & $(0.04)$ & $(0.04)$ \\
\hline Growth opportunities & $0.05^{* * *}$ & $0.05^{* * *}$ & $0.05^{* * *}$ \\
& $(0.02)$ & $(0.02)$ & $(0.02)$ \\
\hline Arellano-Bond & 1.37 & 1.38 & 1.09 \\
\hline Hansen & $178.41(319)$ & $169.02(371)$ & $126.88(319)$ \\
\hline
\end{tabular}

Notes: The table reports the results of GMM, in which the dependent variable is a proxy of firm performance. The lagged dependent variable, for the GMM estimation and the time dummies are included in the model but coefficients are not reported. Between brackets there are the robust standard errors. $(*)(* *)$ and $(* * *)$ indicate statistical significance of each coefficient to a level of $10 \%, 5 \%$ and $1 \%$ respectively. 
of the null hypothesis. The Arellano-Bond test verifies the second-order serial correlation, and it is asymptotically distributed as a standard normal distribution under the null hypothesis of no serial correlation, a hypothesis that, in this case, is not rejected. The results in Column 1 show a statistically significant and positive coefficient of the variable Ownership Concentration, suggesting the existence in Italy of an incentive effect. Considering that the econometric techniques could influence the results, additional empirical analyses have been tested, such as the pooled OLS and fixed effect estimator, with and without the use of instrumental variables (not shown for reasons of brevity). The results are qualitatively identical and do not change the previous conclusions. Column 2 in Table 2 shows the results of the GMM estimates, testing the non-linear relationship. The coefficient of the quadratic term is not statistically significant, therefore, the effect is not shaped by a non-linear relationship. Finally, as robustness, column 3 in Table 2 reports the results of the regression measuring ownership concentration with respect to the total equity share held by the largest 3 shareholders, and the coefficient confirms previous results. In essence, Table 2 shows that ownership concentration may be a harbinger of virtuous governance actions by blockholders, able to capture the major benefits of successful operational and strategic choices in proportion to the equity held. Concerning the control variables, leverage, tangibility, and growth opportunities always have coefficients which are statistically significant and in line with the main literature. In particular, the former two variables show a negative effect, while the growth opportunities variable has a positive effect.

\subsection{Moderating effects}

Our previous results show a positive effect of ownership concentration on performance, but the link could be influenced by other factors. Therefore, further analysis are conducted.

Table 3 shows the empirical evidence with regard to firm-specific moderating variables.

In general, in all the regressions in Table 3, key assumptions regarding the validity of the model and the problems related to second-order serial correlation are verified. Column (1) shows a negative and statistically significant interaction term, so the effect of ownership concentration on performance decreases with increasing debt. Firm leverage influences corporate governance and the way to exercise control, limiting the possibilities for development of firm performance. Column (2) uses as a moderating variable a dummy equal to 1 in case of very high debt ratio, i.e. greater than $75 \%$. In such a situation, the coefficient obtained not only confirms the results of the first column, but it shows that the relationship may become even negative. As further robustness, column (3) shows the results using as a moderating variable a dummy for firms with high debt and difficulties to cover the borrowing costs through operating returns. The results confirm what has been obtained in column (1), as the effect of ownership concentration on performance becomes zero, indicating that financial distress scares the majority shareholders, with a detrimental effect on performance. The results in column (4) give confirmation of the $\mathrm{H} 2$ hypothesis, as the coefficient of interaction variable is positive and statistically significant. In contexts such as those described by Jensen (1986), the 
Table 3. Firm-specific factors as moderators on the relationship between ownership and performance

\begin{tabular}{|c|c|c|c|c|c|c|}
\hline Variables & Adj_Cfroa & Adj_Cfroa & Adj_Cfroa & Adj_Cfroa & Adj_Cfroa & Adj_Cfroa \\
\hline $\begin{array}{l}\text { Ownership } \\
\text { concentration }\end{array}$ & $\begin{array}{c}0.12 * * \\
(0.06)\end{array}$ & $\begin{array}{c}0.07 * * * \\
(0.02)\end{array}$ & $\begin{array}{c}0.08 * * * \\
(0.03)\end{array}$ & $\begin{array}{l}0.03 * \\
(0.02)\end{array}$ & $\begin{array}{c}0.09 * * * \\
(0.03)\end{array}$ & $\begin{array}{c}0.05 * * \\
(0.02)\end{array}$ \\
\hline Leverage & $\begin{array}{l}-0.11^{*} \\
(0.06)\end{array}$ & & $\begin{array}{c}-0.18 * * * \\
(0.04)\end{array}$ & $\begin{array}{c}-0.20 * * * \\
(0.04)\end{array}$ & $\begin{array}{c}-0.26^{* * *} \\
(0.04)\end{array}$ & $\begin{array}{c}-0.24 * * * \\
(0.03)\end{array}$ \\
\hline $\begin{array}{l}\text { Own conc } \times \\
\text { Leverage }\end{array}$ & $\begin{array}{c}-0.17^{*} \\
(0.10)\end{array}$ & & & & & \\
\hline Very high leverage & & $\begin{array}{c}0.01 \\
(0.03)\end{array}$ & & & & \\
\hline $\begin{array}{l}\text { Own conc } \times \text { Very } \\
\text { High Leverage }\end{array}$ & & $\begin{array}{c}-0.11 * * \\
(0.05)\end{array}$ & & & & \\
\hline $\begin{array}{l}\text { High Leverage \& } \\
\text { Low Ebitda/Interests } \\
\text { Dummy }\end{array}$ & & & $\begin{array}{c}0.01 \\
(0.02)\end{array}$ & & & \\
\hline $\begin{array}{l}\text { Own conc } \times \text { High } \\
\text { Leverage \& Low } \\
\text { Ebitda/Interests } \\
\text { Dummy }\end{array}$ & & & $\begin{array}{c}-0.08 * * \\
(0.03)\end{array}$ & & & \\
\hline $\begin{array}{l}\text { Low Leverage \& } \\
\text { High Cash Flow }\end{array}$ & & & & $\begin{array}{c}0.00 \\
(0.02)\end{array}$ & & \\
\hline $\begin{array}{l}\text { Own conc } \times \text { Low } \\
\text { Leverage } \& \\
\text { High Cash Flow }\end{array}$ & & & & $\begin{array}{r}0.07 * * \\
(0.03)\end{array}$ & & \\
\hline Family dummy & & & & & $\begin{array}{c}0.03 \\
(0.03)\end{array}$ & \\
\hline $\begin{array}{l}\text { Own conc } \times \text { Family } \\
\text { dummy }\end{array}$ & & & & & $\begin{array}{c}-0.11 * * \\
(0.04)\end{array}$ & \\
\hline Listing dummy & & & & & & $\begin{array}{c}0.04 \\
(0.03) \\
\end{array}$ \\
\hline $\begin{array}{l}\text { Own conc } \times \text { listing } \\
\text { dummy }\end{array}$ & & & & & & $\begin{array}{c}-0.08^{*} \\
(0.05)\end{array}$ \\
\hline Tangibility & $\begin{array}{c}-0.08^{*} \\
(0.04) \\
\end{array}$ & $\begin{array}{c}-0.09 * * * \\
(0.04)\end{array}$ & $\begin{array}{c}-0.09 * * \\
(0.04) \\
\end{array}$ & $\begin{array}{l}-0.07 \\
(0.04)\end{array}$ & $\begin{array}{l}-0.06 \\
(0.04)\end{array}$ & $\begin{array}{c}-0.09 * * \\
(0.04)\end{array}$ \\
\hline Growth opportunities & $\begin{array}{c}0.05^{* * * *} \\
(0.02)\end{array}$ & $\begin{array}{c}0.04 * * * \\
(0.02)\end{array}$ & $\begin{array}{c}0.05^{* * * *} \\
(0.02)\end{array}$ & $\begin{array}{c}0.05^{* * * *} \\
(0.02)\end{array}$ & $\begin{array}{c}0.05 * * * \\
(0.01)\end{array}$ & $\begin{array}{c}0.05 * * * \\
(0.02)\end{array}$ \\
\hline $\begin{array}{l}\text { Arellano-Bond } \\
\text { Hansen }\end{array}$ & $\begin{array}{c}1.37 \\
187.84 \\
(373)\end{array}$ & $\begin{array}{c}1.41 \\
173.96 \\
(367)\end{array}$ & $\begin{array}{c}1.42 \\
182.21 \\
(427)\end{array}$ & $\begin{array}{c}1.54 \\
188.07 \\
(427)\end{array}$ & $\begin{array}{c}1.30 \\
177.86 \\
(427)\end{array}$ & $\begin{array}{c}1.32 \\
184.43 \\
(427)\end{array}$ \\
\hline
\end{tabular}

Notes: The table reports the results of GMM regressions where the dependent variable is a proxy of firm performance. The lagged dependent variable and the time dummies are included in the model but coefficients are not reported. Between brackets there are the robust standard errors. $\left(^{*}\right)(* *)$ and $(* * *)$ indicate statistical significance of each coefficient to a level of $10 \%, 5 \%$ and $1 \%$, respectively. 
role of the majority shareholder becomes central, as he can maintain the efficiency of governance toward higher performance. The results in column (5) confirm the H3 hypothesis: family control has a negative impact on the effect of ownership concentration on performance. The presence of a politically powerful family generates significant conflicts between large family shareholders and minority investors, even more in markets where the corporate governance system is poor. The results in column (6) confirm the H4 hypothesis: ownership has a positive effect in unlisted companies, while the negative and statistically significant coefficient of interaction variable reveals a negative effect in listed firms. Consequently, given the inefficiencies in the Italian stock market, and conflicts of interest between large shareholders and minority shareholders, increasing ownership concentration in listed firms seems to lead to lower performance.

On the other hand, Table 4 shows the empirical evidence regarding the institutional moderating variables.

Also in this case, in all the regressions in Table 4, key assumptions regarding the validity of the model and the problems related to second-order serial correlation are verified. The results in column (1) confirm the H5 hypothesis: with the introduction of TUF and other reforms following there was an improvement of governance rules and protection of investors, that has reduced the centrality of the majority shareholder. Columns (2) and (3) show that the development of the financial system in Italy does not seem to have affected the relationship between ownership concentration and performance. In fact, the coefficients of the interactions between ownership concentration and, respectively, bank reform dummy and bank development are not statistically significant. Finally, column (4) shows the results concerning the role of crisis. The absence of statistical significance of the coefficient of interaction variable indicates that the blockolders of Italian firms were not active participants in corporate governance during the crisis, which seems to have created panic and fear even in the large shareholders.

\section{Conclusions}

This work examines ownership concentration, using Italy as empirical setting, highlighting its effects on firm performance and focusing on the role of moderating variables, at firm-specific and context-specific level.

First, without considering the moderating factors, the results reveal a positive relationship. The presence of large shareholders may provide a positive contribution in the process of business development, so there is an incentive effect of the blockholders, who identify themselves with the firm, feeling directly responsible and taking advantage from the value created in proportion to equity share held. However, if the sign of the link is mainly positive, it is moderated by several factors and it can switch from positive to negative.

The positive effect of ownership concentration on performance decreases in the presence of high indebtedness and difficulties in meeting commitments with creditors. Leverage influences corporate governance, changing the way of the exercise of command and submitting governance to stringent financial constraints. The tendency of Italian 
Table 4. Institutional factors as moderators on the relationship between ownership and performance

\begin{tabular}{|c|c|c|c|c|}
\hline Variables & Adj_Cfroa & Adj_Cfroa & Adj_Cfroa & Adj_Cfroa \\
\hline Ownership concentration & $\begin{array}{l}0.07 * \\
(0.04)\end{array}$ & $\begin{array}{c}0.03 \\
(0.04)\end{array}$ & $\begin{array}{c}0.04 \\
(0.04)\end{array}$ & $\begin{array}{c}0.02 \\
(0.02)\end{array}$ \\
\hline TUF Dummy & $\begin{array}{l}0.04 * * \\
(0.02)\end{array}$ & & & \\
\hline Own conc $\times$ TUF Dummy & $\begin{array}{l}-0.07 * \\
(0.04)\end{array}$ & & & \\
\hline Bank Reform Dummy & & $\begin{array}{l}-0.02 \\
(0.03)\end{array}$ & & \\
\hline Own conc $\times$ Bank Reform Dummy & & $\begin{array}{c}0.00 \\
(0.05)\end{array}$ & & \\
\hline Bank development & & & $\begin{array}{c}0.07 \\
(0.05)\end{array}$ & \\
\hline Own conc $\times$ Bank development & & & $\begin{array}{l}-0.01 \\
(0.06)\end{array}$ & \\
\hline Crisis Dummy & & & & $\begin{array}{l}-0.01 \\
(0.01)\end{array}$ \\
\hline Own conc $\times$ Crisis Dummy & & & & $\begin{array}{c}0.01 \\
(0.02)\end{array}$ \\
\hline Leverage & $\begin{array}{c}-0.22 * * * \\
(0.03)\end{array}$ & $\begin{array}{c}-0.22 * * * \\
(0.04)\end{array}$ & $\begin{array}{c}-0.24 * * * \\
(0.04)\end{array}$ & $\begin{array}{c}-0.25 * * * \\
(0.03)\end{array}$ \\
\hline Tangibility & $\begin{array}{l}-0.08^{*} \\
(0.04)\end{array}$ & $\begin{array}{c}-0.09^{* *} \\
(0.04)\end{array}$ & $\begin{array}{c}-0.09^{* *} \\
(0.04)\end{array}$ & $\begin{array}{l}-0.08^{*} \\
(0.05)\end{array}$ \\
\hline Growth opportunities & $\begin{array}{c}0.05^{* * *} \\
(0.02)\end{array}$ & $\begin{array}{c}0.05^{* * *} \\
(0.02)\end{array}$ & $\begin{array}{c}0.05^{* * *} \\
(0.02)\end{array}$ & $\begin{array}{c}0.04 * * * \\
(0.01)\end{array}$ \\
\hline $\begin{array}{l}\text { Arellano-Bond } \\
\text { Hansen }\end{array}$ & $\begin{array}{c}1.36 \\
179.99(427)\end{array}$ & $\begin{array}{c}1.38 \\
167.45(427)\end{array}$ & $\begin{array}{c}1.35 \\
181.93(427)\end{array}$ & $\begin{array}{c}0.53 \\
188.42(427)\end{array}$ \\
\hline
\end{tabular}

Notes: The table reports the results of GMM regressions where the dependent variable is a proxy of firm performance. The lagged dependent variable and the time dummies are included in the model but coefficients are not reported. Between brackets there are the robust standard errors. $\left(^{*}\right)(* *)$ and $(* * *)$ indicate statistical significance of each coefficient to a level of $10 \%, 5 \%$ and $1 \%$, respectively.

firms to be dependent on debt, which imposes stricter management rules, generates costs that are often difficult to sustain, and this is critical for value creation. Therefore, the increasing complexity of competitive and organizational contexts requires a redesign of the financial structure in combination with ownership.

In the presence of contexts such as those described by Jensen (1986), in which problems of opportunism are particularly relevant, higher levels of ownership encourage majority shareholders to sustain virtuous processes of value creation. When the problems of opportunism are significant, the role of the majority shareholder becomes central. There- 
fore, in the Italian context, blockholders appear able to protect value by opportunistic choices, offering a system of incentives and control to defend the efficient allocation of resources.

However, higher ownership concentration decreases the performance in family-controlled firms. In a context like the Italian one, characterized by poor quality of the legal environment, the family members are more inclined to extract private benefits. It appears of interest to consider, in future research, whether to limit this effect, for example, by reducing the presence of family members directly involved in management.

The increase in ownership concentration in listed firms leads to negative performance. Inefficiencies in the financial market and a lack of legislative and regulatory action may cause more problems of expropriation by large shareholders against small shareholders in listed firms. From these results it can be understood that the degree of development of a financial system, together with other institutional factors, is essential so that listing can effectively benefit the firm. The results obtained from the analysis provide significant implications for the management as well as policy-makers, suggesting the need for greater efforts to improve the efficiency of the Italian stock market.

Additionally, new regulations and reforms that can improve the protection of minority investors are able to reduce the role of large shareholders. This is in support of the Law and Finance view, which claims that there is a relationship of substitutability between ownership concentration and legal protection in the resolution of the opportunistic problems. Therefore, policy makers should improve the governance systems for firms and provide legal protections for outside investors, designing policies that reduce the costs of the information asymmetries associated with external finance.

This study suggests new research directions in the literature on ownership structure, examining more deeply the effects of moderation on the relationship object of analysis. As a limit of the work, the results are closely based on the Italian context and they may be generalized most effectively only to firms in countries similar to Italy with respect to corporate governance system. For this reason, future research should also explore the effect of moderating variables in a cross-country analysis.

\section{Acknowledgements}

This article is co-funded with support from the European Commission, European Social Fund and the Region of Calabria. The authors declare sole responsibility for this article and the European Commission and the Region of Calabria disclaim any responsibility for any use which may be made of the information contained in the same. The authors wish to thank the participants at the 12th European Academy of Management Conference held in Rotterdam, those ones at the 19th Annual Conference of the Multinational Finance Society held in Krakow, and those ones at the "Research Day Seminar", at the University of Calabria, for their helpful comments. The authors wish also to thank Proff. Marc Deloof, Alfio Cariola and Julio Pindado. 


\section{References}

Barucci, E.; Ceccacci, S. 2005. On ownership structure, investor protection, and company value. Mimeo. Politecnico de Milano.

Blundell, R. W.; Bond, S. R. 1998. Initial conditions and moment restrictions in dynamic panel data models, Journal of Econometrics 87: 115-143. http://dx.doi.org/10.1016/S0304-4076(98)00009-8 Coase, R. H. 1992. The institutional structure of production, American Economic Review 82(4): 713-719.

Cornett, M.; Marcus, A.; Saunders, A.; Tehranian, H.; 2007. The impact of institutional ownership on corporate operating performance, Journal of Banking \& Finance 31: 1771-1794.

http://dx.doi.org/10.1016/j.jbankfin.2006.08.006

Demsetz, H. 1983. The structure of ownership and the theory of the firm, Journal of Law and Economics 26: 375-390. http://dx.doi.org/10.1086/467041

Demsetz, H.; Lehn, K. 1985. The structure of corporate ownership: causes and consequences, Journal of Political Economy 93: 1155-1177. http://dx.doi.org/10.1086/261354

Denis, D. J.; Kruse, T. A. 2000. Managerial discipline and corporate restructuring following performance declines, Journal of Financial Economics 55: 391-424.

http://dx.doi.org/10.1016/S0304-405X(99)00055-0

Desender, K.; Garcia Cestona, M. A.; Crespi Cladera, R. 2008. Stock price performance and ownership structure during periods of stock market crisis: the Spanish case, in AAA 2009. Financial Accounting \& Reporting Section (FARS) Meeting, 2009.

Earle, J. S.; Kucsera, C.; Telegdy, A. 2005. Ownership concentration and corporate performance on the Budapest Stock Exchange: do too many cooks spoil the goulash?, Corporate Governance: an International Review 13(2): 254-264. http://dx.doi.org/10.1111/j.1467-8683.2005.00420.x

Faccio, M.; Lang, L. H. P. 2002. The ultimate ownership of Western European corporations, Journal of Financial Economics 65: 365-395. http://dx.doi.org/10.1016/S0304-405X(02)00146-0

Faccio, M.; Lang, L. H. P.; Young, L. 2001 Dividends and expropriation, American Economic Review 91(1): 54-78. http://dx.doi.org/10.1257/aer.91.1.54

Fratini, F.; Tettamanzi, P. 2007. Corporate performance vis à vis corporate performance: some evidence from Italian companies, in G. Fratini (Ed.). Improving business reporting: new rules, new opportunities, new trends. Milan: Giuffrè Ed.

Gedajlovic, E.; Shapiro, D. 1998. Management and ownership effects: evidence from five countries, Strategic Management Journal 19: 533-553.

http://dx.doi.org/10.1002/(SICI)1097-0266(199806)19:6<533::AID-SMJ957>3.0.CO;2-\#

Jensen, M. 1986. Agency cost of free cash flow, corporate, finance, an takeovers, American Economic Review 76: 323-329.

Jensen, M.; Meckling, W. H. 1976. Theory of the firm: managerial behavior, agency costs, and ownership structure, Journal of Financial Economics 3(4): 305-360.

http://dx.doi.org/10.1016/0304-405X(76)90026-X

La Porta, R.; Lopez-de-Silanes, F.; Shleifer, A. 1999. Corporate ownership around the world, Journal of Finance 54: 471-517. http://dx.doi.org/10.1111/0022-1082.00115

La Porta, R.; Lopez-de-Silanes, F.; Shleifer, A. 2008. The economics consequences of legal origins, Journal of Economic Literature 46(2): 285-332. http://dx.doi.org/10.1257/jel.46.2.285

La Porta, R.; Lopez-de-Silanes, F.; Shleifer, A.; Vishny, R. 2000. Investor protection and corporate governance, Journal of Financial Economics 58: 3-27.

http://dx.doi.org/10.1016/S0304-405X(00)00065-9 
Leech, D.; Leahy, H. 1991. Ownership structure, control type classifications, and the performance of large British companies, Economic Journal 101(2): 1418-1437.

http://dx.doi.org/10.2307/2234893

Lehmann, E.; Weigand, H. 2000. Does the governed corporation perform better? Governance structures and corporate performance in Germany, European Finance Review 4: 157-195.

http://dx.doi.org/10.1023/A:1009896709767

Loderer, C.; Waelchli, U. 2010. Protecting minority shareholders: Listed versus unlisted firms, Financial Management 39(1): 33-57. http://dx.doi.org/10.1111/j.1755-053X.2009.01065.x

Maury, B. 2005. Family ownership and firm performance. Empirical evidence from Western European corporations, Journal of Corporate Finance 12(2): 321-341.

http://dx.doi.org/10.1016/j.jcorpfin.2005.02.002

McConnell, J. J.; Servaes, H. 1990. Additional evidence on equity ownership and corporate value, Journal of Financial Economics 27: 595-612. http://dx.doi.org/10.1016/0304-405X(90)90069-C

Mengoli, S.; Pazzaglia, F.; Sapienza, E. 2009. Effect of governance reforms on corporate ownership in Italy: is it still pizza, spaghetti and mandolino?, Corporate Governance: an International Review 17(5): 629-645. http://dx.doi.org/10.1111/j.1467-8683.2009.00752.x

Miguel, A.; Pindado, J.; De La Torre, C. 2004. Ownership structure and firm value: new evidence from the Spain, Strategic Management Journal 25(2): 1199-1207.

http://dx.doi.org/10.1002/smj.430

Myers, S. C. 2000. Outside equity, Journal of Finance 55(3): 1005-1037.

http://dx.doi.org/10.1111/0022-1082.00239

Pavitt, K. 1984. Sectoral patterns of technical change: towards a taxonomy and a theory, Research Policy 13: 343-373. http://dx.doi.org/10.1016/0048-7333(84)90018-0

Perrini, F.; Rossi, G.; Rovetta, B. 2008. Does ownership structure affect performance? Evidence from the Italian market, Corporate Governance: an International Review 16(4): 312-325.

http://dx.doi.org/10.1111/j.1467-8683.2008.00695.x

Pindado, J.; De la Torre, C. 2011. Capital structure: new evidence from the ownership structure, International Review of Finance 11(2): 213-226.

http://dx.doi.org/10.1111/j.1468-2443.2010.01115.x

Shleifer, A.; Vishny R. W. 1986. Large shareholders and corporate control, Journal of Political Economy 94: 461-488. http://dx.doi.org/10.1086/261385

Shleifer, A.; Vishny, R. W. 1997. A survey of corporate governance, Journal of Finance 52: 737-784. ttp://dx.doi.org/10.1111/j.1540-6261.1997.tb04820.x

Volpin, P. 2002. Governance with poor investor protection: evidence from top executive turnover in Italy, Journal of Financial Economics 64: 61-90.

http://dx.doi.org/10.1016/S0304-405X(02)00071-5

Williamson, O. E. 1988. Corporate finance and corporate governance, Journal of Finance 43(3): 567-591. http://dx.doi.org/10.1111/j.1540-6261.1988.tb04592.x 


\section{APPENDIX 1}

\section{Variable description}

\begin{tabular}{|c|c|}
\hline Variables & Calculation \\
\hline Ownership Concentration & $\%$ of shares directly held by the majority shareholder \\
\hline Ownership Concentration 3 & $\%$ of shares directly held by the first 3 shareholders \\
\hline Adj_Cfroa & $\begin{array}{l}\text { Indicator based on EBITDA/total asset ratio, adjusted for the } \\
\text { specific sector, subtracting, for each year of observation, the } \\
\text { average value obtained from the same industry related firms }\end{array}$ \\
\hline Leverage & Ratio of financial debt to financial debt and equity \\
\hline Tangibility & Ratio of tangible assets to total assets \\
\hline Growth opportunities & $\%$ change in sales from the year $\mathrm{t}$ to year $\mathrm{t}-1$ \\
\hline Year Dummies & $\begin{array}{l}30 \text { dummy variables for each year of the period } 1980-2009 \text {, equal } \\
\text { to } 1 \text { if the observation refers to the corresponding year, } 0 \text { otherwise }\end{array}$ \\
\hline $\begin{array}{l}\text { Low Ebitda/Interests } \\
\text { Dummy }\end{array}$ & $\begin{array}{l}\text { Dummy equal to } 1 \text { in the presence of EBITDA/total financial } \\
\text { interests ratio less than the median, } 0 \text { otherwise }\end{array}$ \\
\hline $\begin{array}{l}\text { High Free cash flow } \\
\text { Dummy }\end{array}$ & $\begin{array}{l}\text { Dummy equal to } 1 \text { in the presence of net income plus depreciation/ } \\
\text { total asset ratio more than the median, } 0 \text { otherwise }\end{array}$ \\
\hline Family Dummy & $\begin{array}{l}\text { Dummy equal to } 1 \text { in the presence of family control, strictly } \\
\text { defined if family members control more than } 25 \% \text { of the shares (in } \\
\text { the absence of other shareholders who have higher equity shares) } \\
\text { or have a role in the management or in the board, } 0 \text { otherwise }\end{array}$ \\
\hline Listing Dummy & Dummy equal to 1 for listed firms, 0 otherwise \\
\hline TUF Dummy & $\begin{array}{l}\text { Dummy equal to } 1 \text { for the years equal to or later than } 1998,0 \\
\text { otherwise }\end{array}$ \\
\hline Bank Reform Dummy & $\begin{array}{l}\text { Dummy equal to } 1 \text { for the years equal to or later than } 1990,0 \\
\text { otherwise }\end{array}$ \\
\hline Bank development & $\begin{array}{l}\text { Private credit by banks and other financial institutions over GDP } \\
\text { (source: World Bank) }\end{array}$ \\
\hline Crisis Dummy & Dummy equal to 1 for the years 2008 and 2009, and 0 otherwise \\
\hline
\end{tabular}

Maurizio La ROCCA is Associate Professor in Management and Finance at University of Calabria. He has published in journals such as the International Small Business Journal, Small Business Economics, Accounting \& Finance. His research interests are in corporate finance, capital structure and corporate governance. He has won a research award from the Italian Academy of Business Administration and Management in 2008. He received a PhD in Business Economics and Management from the University of Catania and was visiting at the University of Chicago's School of Business and Temple University.

Fabiola MONTALTO is PhD candidate in Corporate Finance both at University of Calabria and University of Antwerp (Joint Ph.D.). Her research interests are in ownership and capital structure and cash holding. She has took part in several international conferences. She was visiting at the University of Warwick, the University of Salamanca and the Groupe Sup de Co Montpellier. 